\section{HOVERING THREAT OF CORONAVIRUS (COVID-I9) AROUND PAKISTAN}

\author{
Imdad Kaleem $^{1 \otimes}$, Shahid Bashir ${ }^{2}$
}

January 2020 observed the onset of a new epidemic in Wuhan city of China where hundreds of people were noticed to be suffering from pneumonia like severe acute respiratory syndrome (SARS) which later on termed as New Corona Virus Disease 2019 (COVID-19) by World Health Organization (WHO).' The outbreak in China shook the World as many countries planned on restricting international travel and closing businesses momentarily. ${ }^{2}$ The outbreak of Covid-19, nevertheless, infected every country of the world around 20 million cases worldwide and about 0.7 million confirmed deaths with approximately $19 \%$ mortality rate and $\mathrm{WHO}$ declared it a pandemic on March I I, 2020. ${ }^{3}$

Pakistan is the world's fifth-most-populous country with $207,774,520$ human population. The rising whirl of Covid-19 hit Pakistan following the end of February 2020. Experts predicted the trade operations between Pakistan and China, the students and businesspersons (who frequently cross China-Pakistan border for academic and commercial purposes) to be the vulnerable portal of Covid- 19 in Pakistan. Nevertheless, the Shia pilgrims visiting Iran, where immense religious congregations led to untold Covid-19 surge, were the major entry portal of Covid-19 in Pakistan and officials never reported any Covid-19 case of Chinese transmission in Pakistan.

National Command and Control Centre reported around more than 280 thousand Covid-19 cases with 6,139 deaths on August 13, 2020 overall. ${ }^{4}$ The Covid-19 is on daily exponential rise in Pakistan and the limited resources, lack of equipment and human resource, unavailability of

diagnostic kits and medicines have deteriorated the situation. Pakistan does not have an effective infection disease surveillance system to meet the millennium developmental goals in healthcare. Pakistan is struggling to control diseases such as hepatitis, diarrhea, respiratory diseases, typhoid, measles and many mosquito-borne diseases thereof. ${ }^{5}$

The present outbreak of Covid-19 has affected the whole world although its incidence is low in Pakistan which is continuously struggling to deal with multiple socio-economic factors including poverty, overpopulation, low literacy about common health and health care system issues natural disasters and lack of decisive precautionary approaches. Currently, there is no cure or vaccine available for the virus and therefore "prevention is better than cure".

The preventive measures including lockdown strategies will further add economic crisis to the government and people. The dual frontiers of pandemic and economy could not be combated simultaneously; therefore, the government itself is trying to make a balanced strategy, which could minimally affect the lives of people on both issues. The international funding agencies should take serious notice of this pandemic and its rise in poor country like Pakistan with 220 million populations and come forward to assist Pakistan in fighting out Covid-19 as they are contributing in the eradication of other disease such as tuberculosis, human immunodeficiency virus infection and malaria. The smart lockdown proved to be the best strategies to combat this pandemic and have produced significant results in not only reducing the spread of

THIS ARTICLE MAY BE CITED AS: Kaleem I, Bashir S. Hovering threat of Coronavirus (Covid-19) around Pakistan. Khyber Med Univ J 2020; I 2(3):260. DOI: I0.35845/kmuj.2020.20440.
I. Department of Bioinformatics and Bioscience, COMSATS Institute of Information Technology (CIIT), Islamabad 45600, Pakistan.

2. Neuroscience Center, King Fahad Specialist Hospital, Dammam, Kingdom of Saudi Arabia.

Email『: shahidbpk।3@gmail.com

disease but also running the wheel of economy. The government of Pakistan is further planning to narrow the margin of lockdown to micro smart lockdown to boost up economic activities and eradicate the load of Covid- 19.

\section{REFERENCES}

I. World Health Organization (WHO). WHO Coronavirus Disease (COVID19) Dashboard. Data last updated 2020/8/12. [Accessed on: August 12 , 2020]. Available from URL: https://covid I9.who.int/

2. Li Q, Guan X, Wu P, Wang X, Zhou L, Tong Y, et al. (2020). Early Transmission Dynamics in Wuhan, China, of Novel Coronavirus-Infected Pneumonia. New Eng J Med 2020;382(I3): I| 199-1207. DOI: 10.1056/NEJMoa200I 316.

3. World Health Organization (WHO). Covid-19 strategic preparedness and response plan. Country preparedness and response status for COVID- 19 as of II August 2020. [Accessed on: August II, 2020]. Available from URL: https://www.who.int/publications/i/it em/updated-country-preparednessand-response-status-for-covid-19-asof- I I-August-2020.

4. Government of Pakistan. Coronavirus in Pakistan. June 12, 2020. [Accessed on: June 12, 2020]. Available from URL: http://covid.gov.pk/stats/ pakistan.

5. Rizvi A, Bhatti Z, Das JK, Bhutta ZA Pakistan and the Millennium Development Goals for Maternal and Child Health: progress and the way forward. Paediatr Int Child Health 20I5;35(4):287-97. DOI: 10.1080/ 20469047.20I5.II09257.

\begin{tabular}{|c|}
\hline CONFLICT OF INTEREST \\
Authors declared no conflict of interest \\
FINANCIAL DISCLOSURE \\
NIL \\
\hline
\end{tabular}

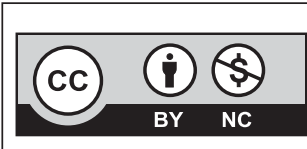

This is an Open Access article distributed under the terms of the Creative Commons Attribution-Non Commercial 2.0 Generic License. 